\title{
O PESQUISAR EM AÇÃo
}

Por Marcia Moraes $\star$

FONSECA, T. M. G.; NASCIMENTO, M. L. do; MARASCHIN, C. Pesquisar na diferença: um abecedário. Porto Alegre: Sulina, 2012.

\section{Resumo}

O objetivo deste texto é fazer uma resenha do livro intitulado Pesquisar na Diferença, uma publicação coletiva, inspirada pelo Abecedário de Gilles Deleuze. O livro é composto por verbetes, cada um dos quais ligados a uma ação que se faz presente no pesquisar, tal como é entendido pelo grupo de pesquisadores que compõe o volume. Observar, desejar, escrever, afetar, tatear são alguns dos verbetes presentes neste livro. Os autores que se reúnem nesta publicação definem a pesquisa como uma ação encarnada e situada, como uma prática de composição de mundo e que por isso mesmo, é eminentemente política. É a partir deste ponto que os verbetes são definidos.

Palavras-chave: pesquisar; conhecer; intervir.

\section{RESEARCH IN ACTION}

\begin{abstract}
The aim of this paper is to present a review of the book titled Pesquisar na Diferença, a publishing collective, inspired by "Deleuze's Abecedary". The book consists of entries, each of which is linked to an action that is imanent to research, as understood by the group of researchers who make up the volume. Observe, wish, write, affect, groping are some of the entries in this book. The authors Who gather in this publication defines research as an action embodied and situated, as a practice of composing world which is eminently political. It is from this point that the entries are defined.
\end{abstract}

Keywords: to research; to know; to interfere.

\footnotetext{
^ Psicóloga. Doutorado em Psicologia Clínica pela Pontifícia Universidade Católica de São Paulo. Pós-doutorado em Psicologia Social pela Universidade do Estado do Rio de Janeiro/Lancaster University. Professora Associada do Departamento de Psicologia da Universidade Federal Fluminense. Endereço: Universidade Federal Fluminense, Departamento de Psicologia. Campus do Gragoatá s/no Bloco O, sala 310. São Domingos - Niteroi, RJ - Brasil. CEP: 24210-350.

E-mail:mmoraes@vm.uff.br
} 
O livro "Pesquisar na diferença: um abecedário" é inspirado no Abecedário de Deleuze e tem como proposta criar um abecedário a partir de verbos, de ações, suscitadas pelo processo de pesquisar. Logo de saída é preciso dizer que não se trata de um dicionário porque o que está em jogo não é descrever os significados dos termos que constam do livro. Antes, o que se põe em cena é o pesquisar como uma ação que se desdobra, se desfaz, se refaz em várias outras ações: xeretar, acoplar, desejar, diferir, escutar, soprar, zerar e outras tantas. Trata-se, portanto, mais do que de definir o significado do pesquisar, de fazer proliferar os seus sentidos e de multiplicar as suas derivas. Não à esmo, mas no escopo de uma certa aposta epistemológica, ética e política que perpassa todo o livro: a produção de conhecimentos é via de afirmação de outros possíveis, "outros mundos coalescentes a esse nosso atual presente [...] [o] Abecedário de Pesquisa afirma um modo especial de pesquisar, relacionando-o a um processo de produzir fissuras no duro gelo das subjetivações instituídas, um quebra-cabeça, por cujas fendas possíveis se deixe entrever aquilo que denominamos pensamento" (p.10). Produzir fissuras naquilo que é dado ou tomado como não problemático: é justamente aí que ética, política e epistemologia se encontram inextrincavelmente entrelaçadas.

Com o Abecedário, o que se propõe é afirmar um modo de conhecer situado, que escape, como salienta Haraway (1995), aos dois extremos que obliteram o pensamento, o relativismo e a totalização, dois lados de uma mesma moeda. Ambos, relativismo e totalização, negam o caráter situado do conhecer, negam a corporificação e o engajamento político de todo ato de conhecimento. Nas palavras da autora, relativismo e totalização ambos são, truques de deus. Isto é, negam a parcialidade de qualquer conhecimento, o fato inexorável de que todo conhecer é datado, situado, localizado no tempo, no espaço, no jogo político. Ambos reduzem o conhecer a uma só ação no infinitivo: ver. Não qualquer forma de ver. Mas uma visão desencarnada, deslocalizada: uma visão de sobrevoo sobre um mundo qualquer e que não presta contas do mundo que engendra. A provocação de Haraway (1995) é aguda e, do mesmo modo que os autores do Abecedário, visa produzir fissuras naquilo que parece dado e autoevidente. Fissurar o truque de deus que por tanto tempo fez com que a ciência fosse escrita com maiúsculas. Ousar afirmar que toda ótica é uma política de posicionamentos e que se conhecer está ligado a ver, e Haraway (1995) afirma que está, é porque toda visão requer instrumentos, mediações, conexões, posições. Trata-se, portanto, não de um ver abstraído de qualquer corporificação, mas de um ver encarnado. Conhecemos, pois, partir de algum lugar, com alguém, num certo tempo e espaço, com certas mediações e não outras.

Nas páginas iniciais do Abecedário somos advertidos de que seus autores retomam o ver em suas relações com conhecer, mas aí fazendo uma torção. É que o ver se conecta a desejar, inventar mais do que revelar. Ver imanente ao corpo, à pesquisa em ação. Ver o que é imperceptível aos olhos de um certo paradigma de ciência. É assim que a pesquisa-vidência "nunca seria concluída ou acabada, mas que, desde seus barrocos entrelaçamentos mentais, levaria a outros e tantos mais mundos quanto nosso desejo permitir" (p.10). 
O Abecedário convoca o leitor a tomar parte nas ações do pesquisar, a se interrogar, ele também, sobre os verbos que o pesquisar lhe suscita. De minha parte, recebo este livro como um gesto de generosidade deste grupo de autores, como um convite para que eu coloque em cena as ações de pesquisa nas quais me engajo cotidianamente. Por isso, o livro não esgota o guaguejar que se anuncia na introdução, aquele guaguejar das letras que se repetem para produzir diferença. É que nós, leitores, gaguejamos junto com os autores e neste movimento, tomamos parte da política de pesquisa que este livro afirma. Uma política de pesquisa que, sem dúvida, é mutirão de muitos. Pois que estes autores - e você, leitor, disso fará parte quando tomar este livro nas mãos e a ele se entregar - nos convidam para este mutirão de muitos no qual tecer o conhecimento é uma forma de construir mundos menos organizados por eixos de dominação.

\section{REFERÊNCIA}

HARAWAY, D. Saberes Localizados: a questão da ciência para o feminismo e o privilégio da perspectiva parcial. Cadernos Pagu, [S.1.], n. 5, p. 04-41, 1995. 
